\title{
STUDENT PERCEIVED EMPLOYABILITY WITH REFERENCE TO MEDIA STUDIES: VALIDATING A MODEL OF KEY DETERMINANTS
}

\author{
Shikha Agnihotri \\ Research Scholar, Amity University-Noida \\ Puja Sareen \\ Associate Professor, Amity University-Noida \\ P Sivakumar \\ Director, I Business Institute-Greater Noida
}

\begin{abstract}
The motive of this research is to investigate the employability of media students. It aims to validate a holistic model of key determinants of perceived employability in Indian context. These factors emerge from internal background such as academic performance, contacts, generic skills and self-confidence of students; external background such as university role and labor market. Psychometric properties of the proposed scale were assessed including validation at exploratory and confirmatory level; reliability; convergent and discriminant validity. Further model fit estimates were demonstrated. The study results in a comprehensive model determining the perceived employability of media students. The practical implications of this study include identification of university's contribution in employability of students and providing a foundation for higher education policy formulation and amendments in media studies program. The novelty of this study is validating the measurement tool for assessing employability of media students in Indian context. This study will contribute towards improvement of perceived employability of media students and augmentation of literature in media studies.
\end{abstract}

Keywords: Generic Skills, Self-Confidence, Perceived Employability, Higher Education, Human Capital, Social Capital.

\section{INTRODUCTION}

Employability and its determinants had emerged as a bewitching area of research for researchers, educationalist, policy makers and society at large. Continuous increase in supply of graduate students has surpassed the demand created by labor market resulting in an increase in competition (Newton, 2015; Pitan and Adedeji, 2012; Tomlinson, 2007). Although, employability doesn't mean that student will be able to get the desired job but, it enhances the likelihood of getting desired job by attaining skills that labor market demands (Caballero et al., 2014; Pitan, 2016; Rothwell et al., 2009).

Various studies aims to identify internal factors influencing employability such as inherited skills and skills acquired during studies (Andrews and Higson, 2008; Dacre and Sewell, 2007; Pitan, 2016, Yusof et al., 2012), personal circumstances and work flexibility (Mcquaid and Lindsay, 2005), personal contacts and reflection and evaluation (Pitan, 2016) which can help the student in searching and attaining a job (Mcquaid and Lindsay, 2005; Rothwell and Arnold, 2007). Self-confidence predicts employability of employees (Kim et al., 2015) and students (Chou and Shen, 2012). Selfconfidence mediates the relationship between skills and perceived employability of students (Dacre and Sewell, 2007; Gonzalez et al., 2017). Academic performance of students leads to enhancement of perceived employability (Dacre et al., 2014).

Few other studies aim to identify external factors surrounding an individual and enhancing employability (Gamboa et al., 2007). Universities are responsible for smooth transitioning of students to labor market, by enhancing their employability (Harvey, 2003). One of the commonest ways to assess university's role in student employability is through graduate employment rate. This method was criticized; keeping in mind that a lot of students wait for their desired job to start their career. (Dacre-Pool et al., 2014; Pitan, 2016). Other external factors are labor 
market conditions in the concerned geographical area (Chou and Shen, 2012; Wittekind et al., 2010), efforts by faculties of student's university in connecting the students with labor market through internships and industrial projects (Pitan, 2016; Olkin, 2004) and teacher's effectiveness in imparting knowledge and developing skills in students required for employment (Tsui et al., 1997). However, as per our knowledge no researches in media studies have proposed or validated a model for perceived employability of media students. Moreover, this study aims to validate the proposed holistic model of employability in Indian context. Moreover, students are the main respondents for data collection in most of the studies. This research gap is addressed in the present study as the data is collected from HR professionals; who tends to provide more reliable and authentic perception of student employability. In light of the above, our specific research questions pertaining to employability are as follows:

- To systematically construct a scale to measure perceived employability of students from media studies.

- To identify various components of employability discernible from perception of HR professionals.

- To report the psychometric analysis of the proposed scales for measuring employability as per respondent's perception.

- To report model fit estimates of the proposed model for perceived employability.

Further, the paper is organized as follows:

Section two represents literature review constituting theoretical framework and proposed conceptual framework, Section three constitutes research methodology and data analysis. Section four is composed of theoretical, practical and managerial implications of the study. Lastly, section five constitutes limitations of the study, recommendation for future research and discussion \& conclusion.

\section{Theoretical Framework}

Employability is examined in various academic disciplines including human resource management and development studies, education studies, media studies and cognitive psychology (Gonzalez et al., 2017;
Knight and Yorke, 2002). Researchers have analyzed the concept of employability and its determinants through various theoretical lenses such as the human capital theory (Gonzalez et al., 2017, Wittekind et al., 2010), social capital theory (Ngoma and Ntale, 2016). Employability has been conceived differently by various researchers. However, drawn from various theoretical frameworks, Hillage and Pollard (1998) has defined employability comprising of individual's personal assets and his/her circumstances and labor market situation. As proposed by Knight and Yorke (2002), employability is framed in context of cognitive and social psychology. McQuaid and Lindsay (2005), explained employability in terms of individual's personal circumstances and internal/external factors. "The key to employability" model proposed by Dacre and Sewell (2007), comprised of various components from "CareerEDGE" model, selfefficacy, self-esteem and self-confidence. Perceived employability has also been defined as an individual's self-perception regarding his/her capability of attaining and retaining employment and managing to get a new one, as and when required (Gonzalez et al., 2017; Hillage and Pollard, 1998; Kim et al., 2015).

Studies referring to the factors affecting employability are mainly theoretical (Finch et al., 2013) due to limited number of diagnostic tools (Gonzalez et al., 2017). In the existing validated scales, only exploratory analysis is performed (Chou and Shen, 2012; Rothwell et al., 2008). Few studies demonstrating confirmatory validation, lacks analysis of psychometric properties, convergent and discriminant validity (Dacre et al., 2014). Empirical studies on perceived employability mainly propose models which explain how employability is formed. Kim et al., (2015), explained $23 \%$ of variance in perceived employability of employees on the basis of variables such as role breadth self-efficacy, voluntary behaviour and self-esteem. Qenani et al., (2014), proposed a regression model relating student's expectation regarding employment after graduation and its determining factors explaining a variance of $12.3 \%$

\section{A holistic model of perceived employability}

This study is intended to validate perceived employability scale and contribute to the existing literature. Human capital theory 
emphasizes that education and basic training leads to increase in earnings and productivity by providing students with appropriate knowledge and skills (Becker, 1994). As per social capital theory, personal network and informational sources helps in building social capital of an individual which ultimately helps in searching and attaining desired job (Fugate et al., 2004; Seibert et al., 2001). Social capital theory defines the benefit an individual gets from its social relationships and embedded resources leading to career success (Brut, 1992). Social cognitive career theory (Hackett et al., 1994) states that career interest influences academic and occupational choices and acts as predictor of employability. Referring the above relevant literature, following model is proposed: of enhancing perceived employability. According to Pitan and Muller (2019), student perceived employability, measured across gender and different academic discipline is an impression of his/her self-confidence.

\section{Internal factors}

Internal factors is the perception of an person regarding his/her own personal attributes which helps them in searching and obtaining desired job (Gonzalez et al., 2017; Mcquaid and Lindsay, 2005; Rothwell at el., 2008). For the purpose of this study, internal factors are divided into person specific (academic performance, generic skills, reflection and evaluation) and environment specific (contacts). Academic performance refers to self-perception and satisfaction level of students regarding their academic scores and grades (Rothwell et al., 2008). Academic

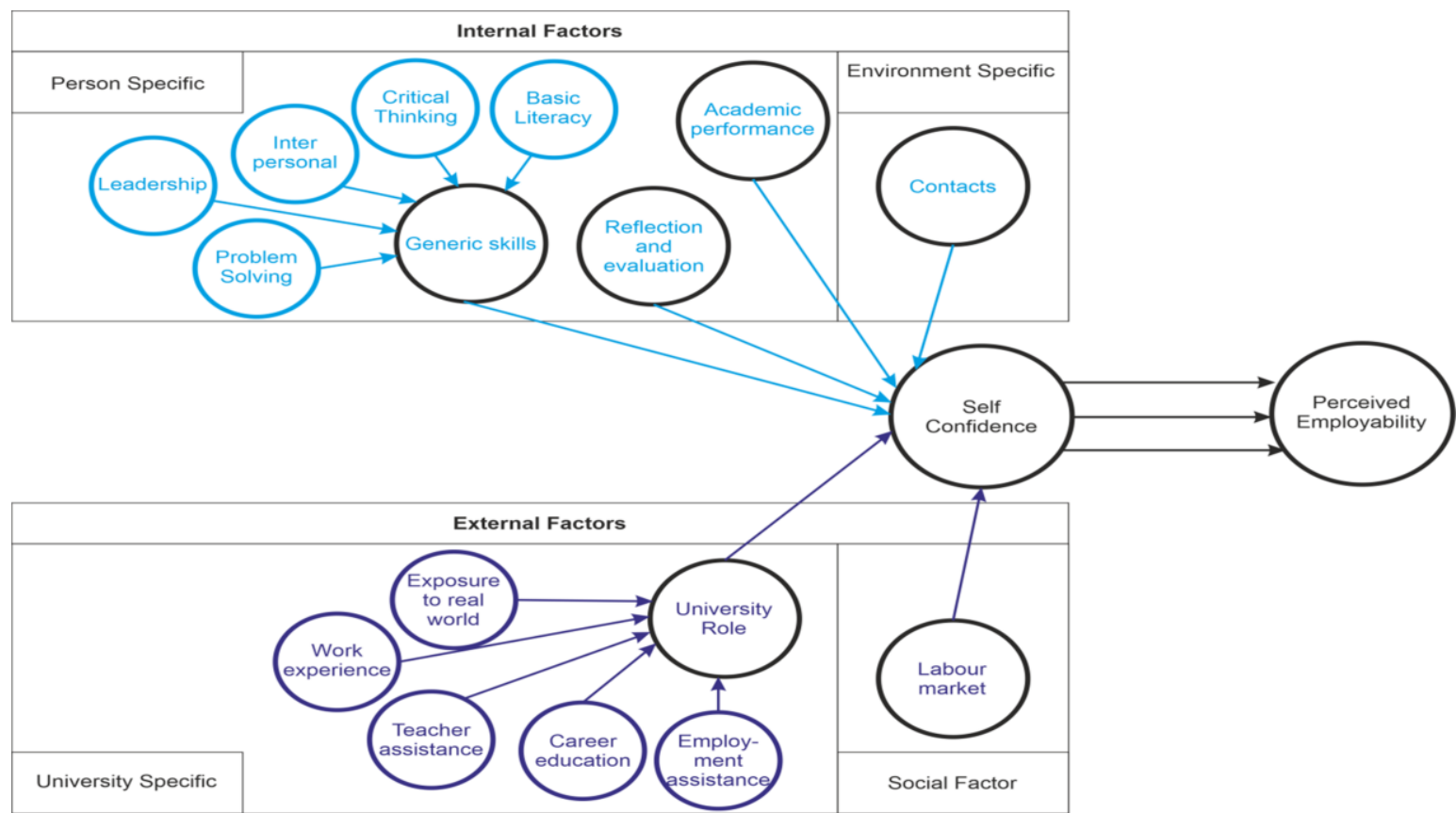

Fig. 1: Proposed Conceptual Model (Adapted from Gonzalez et al., 2017)

Self-confidence is the way an individual portray himself to the outside world about his capacity of gaining and maintaining employment (Dacre and Sewell, 2007; Gonzalez et al., 2017; Wettikind et al., 2010). Self-confidence is found to be a predictor of perceived employability of students (Chou and Shen, 2012). People having self-confidence reflect their attributes, scholarly achievements in situation like job search and interviews (Onyishi et al., 2015; Gonzalez et al., 2017; Wettikind et al., 2010). Qenani et al., (2014), stated that self-confidence is an effecient way performance is a predictor of self-confidence and thereby enhances perceived employability (Qenani et al., 2014).

Generic skills indicate the self-perception of students regarding transferable and/or nontechnical skills essential to perform work at all the levels at workplace (Bridgstock, 2009; De Guzman and Choi, 2013). Generic skills are most commonly known as employability skills which represent basic knowledge, skills and abilities required at all jobs at workplace (Rosenberg et al., 2011; Overtoom, 2000). 
Generic skills considered are basic literacy and numeracy skills, critical thinking skills, interpersonal skills, leadership skills, problemsolving skills (Bridgstock, 2009; Finch et al., 2013; Mcquaid and Lindsay, 2005; Rosenberg et al., 2011; Tariq and Durrani, 2011). To our knowledge, self-confidence acting as a mediator between perceived employability and skills are tested theoretically by Dacre and Sewell, (2007) and empirically by Gonzalez et al., (2017).

Reflection and evaluation indicates student having an opportunity to reflect and evaluate learned experiences resulting in improvement of performance (Pitan, 2016). Reflection is the strength of an individual to project his/her skills in the best possible way to prospective employer. Reflection is also referred as achievement which helps the student, to not only secure employment but to maintain the same (Moon, 2004). Also, reflection and evaluation are found to develop generic skills (Moon, 2004). Reflection and evaluation play significant role in self-confidence, which consequently enhances perceived employability (Dacre-Pool and Sewell, 2007; Leong, 2012; Pitan, 2016). Employers prefer candidates who can put forth their views well (Srivastava and Prabhakar, 2020).

Contacts refer to an individual's perception regarding his/her personal contacts (Gonzalez et al., 2017; Mcquaid and Lindsay, 2005) and social network contacts which might help him/her to quest and obtain employment (Hernandez-Fernaud et al., 2011). According to Sabatini (2009), contacts of an individual develop by providing supportive social environment. As per Samer Abdel Hadi (2019), representing cognitive empathy guides an individual during social interactions. Sachdeva and Tripathi (2019) highlighted the importance and emergence of online networking on social life and interaction among individuals.

Perceived self-confidence not only enhances perceived employability of students but also act as a link between internal factors (academic performance, contacts, generic skills, personal circumstances of students) and perceived employability (Dacre and Sewell, 2007; Dacre et al., 2014; Gonzalez et al., 2017).

External factors
In words of Gamboa et al., (2007), external factors are the factors surrounding an individual and acting as determinants of employability. Literature suggests inclusion of external and internal factors while assessing perceived employability (Fugate et al., 2014; Gonzalez et al., 2017; Mcquaid and Lindsay, 2005). For this study, external factors are divided into university specific factors comprising of career education, employment assistance, and exposure to real world activities, exposure to work experience; and social factor referred to labor market.

Career education refers to the process of planned experiences facilitating selfawareness, opportunity analysis, decision making and transitional training in students (Watts, 2006). Career education is essential for employability as it enable the student to know how, where and when to utilize and project their generic skills and academic achievements (Bridgstock, 2009; Watts, 2006). Literature suggests that students do not think about their career and do not look for assistance regarding career planning until graduation, which is too late (Bridgstock, 2009; Kinash; 2015; Pitan and Adedeji, 2014). Pitan and Muller (2019), stated that student's awareness of available opportunities help them in enhancing their employability. Employment assistance refers to employment related assistance provided by the university and faculty such internship coordination, job exchange program and post interview follow up by university's faculty (Caballero et al., 2014). Actions taken by faculty of the university, plays an important role in student's employability (Caballero et al., 2014; Qenani et al., 2014).

Exposure to real world activities refer to all forms of alliance with employers such as industrial visit, corporate involvement in curriculum design and alumni interaction with students lead to enhanced employability (Creasy, 2013; Ehiyazaryan and Barraclough, 2009; Pitan, 2016). Ehiyazaryan and Barraclough (2009), reported that exposure to real world activities give opportunities to students for reflection and evaluation of skills and also enhances their self-confidence. As mentioned by Kinash et al., (2015), university should closely work with employers, so as to provide exposure of real world of work. According to Pitan and Muller (2019), 
experiential learning leads to enhancement of student employability.

Exposure to work experience refers to a student's exposure and participation in industrial training/summer internship which provide them learning opportunities, considered valuable to expected employer (Finch et al., 2013; Jackson, 2015; Pitan, 2016). Teacher assistance refers to the perception of student regarding his/her teacher's ability to impart knowledge and to provide general help, which develop employment related attitude in them (Gonzalez., 2017; Tsui et al., 1997).

Labor market indicate the perception of student regarding demand of the stream pursued by them, specifically within their geographic vicinity (Mcquaid and Lindsay, 2005; Rothwell, 2008). Few theoretical studies considered labor market as an influential variable for perceived employability (Hillage and Pollard, 1998; Mcquaid and Lindsay, 2005). Sok et al., (2013) and Wettikind et al., (2010), empirical researches consider labor market as an important variable of employability for workers; and student's employability by Chou and Shen (2012). Pitan and Muller (2019), reported that realization of labor market situation helps in enhancing student employability. As per Peeters et al., (2020), employees who are aware of labor market opportunities, tends to have high perceived employability.

\section{Research Methodology \\ Research Design, Process and Participants}

Descriptive research design is used in this study to describe the phenomena of perceived employability and its key determinants.

Population studied for this study comprised of HR professionals in Delhi/NCR location. Using stratified sampling technique, colleges approved by AICTE and having NBA affiliation were selected. A total of 23 colleges were selected; and data regarding recruiters of media students was collected from websites. A structured questionnaire was circulated to 700 HR professionals. A total of 410 responses were received with no missing data. Regarding outliers, the maximum and minimum score values are within limits and no data adjustment was required.

\section{Measures}

Variables were measured through reflective scales, using seven point likert scales starting from 1-"strongly disagree" to 7-"strongly agree". Items with similar context were adapted from earlier studies.

Self-confidence: The variable self-confidence is measure through three items adapted from Gonzalez et al., (2017) and Rothwell et al., (2008). One of the sample item is "The students are generally confident of success in job interviews and selection events".

Academic performance: The variable academic performance is measured through three items adapted from Gonzalez et al., (2017) and Rothwell et al., (2008). One of the sample item is "The students achieve high grades in their studies".

Contacts: The variable contacts are measured through three items adapted from Gonzalez et al., (2017). One of the sample item is "Students have personal contacts that can help them find work".

Generic skills: A total of five skills were measured:

Basic literacy and numeracy skills were measured through four items adapted from Finch et al., (2013) and Rosenberg et al., (2011). One of the sample item is "The students can perform basic computations and approach practical problems with different mathematical techniques".

Critical thinking skills were measured through six items adapted from Finch et al., (2013) and Rosenberg et al., (2011). One of the sample item is "The students can generate new ideas".

Interpersonal skills were measured through five items adapted from Finch et al., (2013) and Rosenberg et al., (2011). One of the sample item is "The students contribute to group efforts".

Leadership skills were measured through five items adapted from Finch et al., (2013) and Rosenberg et al., (2011). One of the sample item is "The students can exert a high level of effort and persevere toward goal attainment".

Problem solving skills were measured through five items adapted from Heimler (2010) and 
Roman (2011). One of the sample item is "The students can sort out the relevant data to solve a problem".

Reflection and evaluation: The variable reflection and evaluation is measured through five items adapted from Milner (2008) and Pitan (2016). One of the sample item is "The students are able to reflect whatever they have learnt"

University Role: It is measured through the following variables:

Career education: The variable career education is measured through five items adapted from Milner (2008) and Pitan (2016). One of the sample item is "The students are able to produce an up-to-date CV targeted to applications".

Employment assistance: The variable employment assistance is measured through three items adapted from Caballero et al., (2014) and González et al., (2017). One of the sample item is "Internships are coordinated by the university faculty with firms/institutions".

Exposure to real world activities: The variable exposure to real world activities is measured through five items adapted from Milner (2008) and Pitan (2016). One of the sample item is "Alumni often visit the university to talk about their career paths and possible opportunities in their company".

Exposure to work experience: The variable exposure to work experience is measured through five items adapted from Milner (2008) and Pitan (2016). One of the sample item is "The students have been exposed to work experience through internship".

Teacher assistance: The variable teacher assistance is measured through four items adapted from González et al., (2017) and Tsui et al. (1997). One of the sample item is "Teachers are willing to listen to their students problems regarding employment".

Labor Market: The variable labor market is measured through four items adapted from González et al., (2017) and Rothwell A at el., (2009). One of the sample item is "People in management career are in high demand in the external labor market".

\section{RESULTS}

Preliminary analysis

Table 1 represents mean and standard deviation. All the variables have scored more than half the scale. Mean score of perceived employability is highest with a score of 4.01 , followed by reflection and evaluation with a score of 3.9 .

\begin{tabular}{|l|l|l|}
\hline \multicolumn{3}{|c|}{ Table 1: Descriptive Statistics } \\
\hline Variable & M & SD \\
\hline Generic Skills & 3.79 & 0.796 \\
\hline Academic Performance & 3.84 & 1.25 \\
\hline University Role & 3.87 & 0.911 \\
\hline Contacts & 3.86 & 1.21 \\
\hline Labor Market & 3.82 & 1.21 \\
\hline Reflection and evaluation & 3.92 & 1.14 \\
\hline Self Confidence & 3.9 & 1.19 \\
\hline Perceived employability & 4.01 & 1.05 \\
\hline
\end{tabular}
Source: Author's Calculation

Measurement scales

Content validity was established through review by five experts from corporate and academic discipline. As recommended by experts, few items were reworded and 2-3 were eliminated. EFA was conducted to determine unidimensionality; PCA with varimax rotation was conducted, which explained a variance of nearly $80 \%$ and communalities were above the threshold limit of 0.5 (Hair et al., 1999). KMO measure of sample adequacy was more than 0.8 for all the items, above the minimum value of 0.5 (Kaiser, 1975). Generic skills and university role were denoted as second order multidimensional structure and all other variables were denoted as unidimensional structure. Generic skills comprises of five factors such as basic literacy and numeracy skills, critical thinking skills, interpersonal skills, leadership skills and problem solving skills. University role comprises of career education, employment assistance, exposure to real world activities, exposure to work experience and teacher assistance.

Table 2 indicates reliability and convergent validity. For reliability, three tests were conducted (Anderson and Gerbing, 1998): resulted cronbach's a was above the minimum value of 0.70 (Nunnally, 1978), average variance explained was above the minimum value of 0.50 (Sharma, 1996) and composite reliability crossed the minimum value of 0.70 
(Atul et al., 2020; Hair et al., 2019; Luque, 2000) for all the variables. For convergent validity, factor loads were tested to be significant and above the minimum value of 0.50 (Hildebrandt, 1987). These results corroborate scale reliability and convergent validity.

Table 2: Reliability and Convergent Validity of the scale

\begin{tabular}{|c|c|c|c|c|}
\hline Construct dimensions & Factor loads & Cronbach's a & AVE & $\mathrm{CR}$ \\
\hline \multicolumn{5}{|l|}{ Items } \\
\hline Generic Skills & & 0.93 & 0.71 & 0.98 \\
\hline Basic Literacy & & 0.93 & 0.82 & 0.94 \\
\hline BL1 & $0.87^{* * *}$ & & & \\
\hline BL2 & $0.80^{\star * *}$ & & & \\
\hline BL3 & $0.79^{* * *}$ & & & \\
\hline BL4 & $0.81^{* * *}$ & & & \\
\hline Critical Thinking & & 0.87 & 0.60 & 0.89 \\
\hline CT1 & $0.64^{* * *}$ & & & \\
\hline CT2 & $0.82^{* * *}$ & & & \\
\hline CT3 & $0.72^{* * *}$ & & & \\
\hline CT4 & $0.76^{* * *}$ & & & \\
\hline CT5 & $0.78^{\star * *}$ & & & \\
\hline CT6 & $0.67^{* * *}$ & & & \\
\hline Interpersonal & & 0.91 & 0.73 & 0.93 \\
\hline IP1 & $0.76^{* * *}$ & & & \\
\hline IP2 & $0.83^{* * *}$ & & & \\
\hline IP3 & $0.78^{* * *}$ & & & \\
\hline IP4 & $0.80^{* * *}$ & & & \\
\hline IP5 & $0.73^{* * *}$ & & & \\
\hline Leadership & & 0.94 & 0.80 & 0.95 \\
\hline LR1 & $0.75^{\star * *}$ & & & \\
\hline LR2 & $0.76^{* * *}$ & & & \\
\hline LR3 & $0.77^{* * *}$ & & & \\
\hline LR4 & $0.76^{* * *}$ & & & \\
\hline LR5 & $0.81^{* * *}$ & & & \\
\hline Problem Solving & & 0.95 & 0.82 & 0.96 \\
\hline PS1 & $0.83^{* * *}$ & & & \\
\hline PS2 & $0.80^{* * *}$ & & & \\
\hline PS3 & $0.81^{* * *}$ & & & \\
\hline PS4 & $0.80^{* * *}$ & & & \\
\hline PS5 & $0.81^{* * *}$ & & & \\
\hline Academic Performance & & 0.90 & 0.81 & 0.92 \\
\hline AP1 & $0.71^{* * *}$ & & & \\
\hline $\mathrm{AP2}$ & $0.72^{* * *}$ & & & \\
\hline AP3 & $0.69^{* * *}$ & & & \\
\hline University Role & & 0.94 & 0.78 & 0.98 \\
\hline Career Education & & 0.93 & 0.78 & 0.94 \\
\hline CE1 & $0.72^{* * *}$ & & & \\
\hline CE2 & $0.73^{* * *}$ & & & \\
\hline CE3 & $0.83^{* * *}$ & & & \\
\hline CE4 & $0.77^{* * *}$ & & & \\
\hline CE5 & $0.82^{* * *}$ & & & \\
\hline Employment Assistance & & 0.95 & 0.89 & 0.96 \\
\hline EA1 & $0.68^{* * *}$ & & & \\
\hline EA2 & $0.68^{* * *}$ & & & \\
\hline EA3 & $0.66^{* * *}$ & & & \\
\hline
\end{tabular}




\begin{tabular}{|c|c|c|c|c|}
\hline Construct dimensions & Factor loads & Cronbach's a & AVE & $\mathrm{CR}$ \\
\hline $\begin{array}{l}\begin{array}{l}\text { Exposure } \\
\text { activities }\end{array} \\
\text { to }\end{array}$ & & 0.93 & 0.78 & 0.94 \\
\hline ERW1 & $0.68^{* * *}$ & & & \\
\hline ERW2 & $0.71^{* * *}$ & & & \\
\hline ERW3 & $0.71^{* * *}$ & & & \\
\hline ERW4 & $0.69^{* * *}$ & & & \\
\hline ERW5 & $0.66^{* * *}$ & & & \\
\hline Exposure to work experience & & 0.93 & 0.82 & 0.94 \\
\hline EWE1 & $0.58^{* * *}$ & & & \\
\hline EWE2 & $0.76^{* * *}$ & & & \\
\hline EWE3 & $0.64^{* * *}$ & & & \\
\hline EWE4 & $0.73^{* * *}$ & & & \\
\hline Teacher assistance & & 0.94 & 0.88 & 0.95 \\
\hline TS1 & $0.76^{* * *}$ & & & \\
\hline TS2 & $0.77^{* * *}$ & & & \\
\hline TS3 & $0.77^{* * *}$ & & & \\
\hline Labor Market & & 0.92 & 0.82 & 0.94 \\
\hline LM1 & $0.74^{* * *}$ & & & \\
\hline LM2 & $0.73^{* * *}$ & & & \\
\hline LM3 & $0.76^{* * *}$ & & & \\
\hline LM4 & $0.69^{* * *}$ & & & \\
\hline Reflection and Evaluation & & 0.94 & 0.80 & 0.95 \\
\hline RE1 & $0.72^{* * *}$ & & & \\
\hline RE2 & $0.72^{* * *}$ & & & \\
\hline RE3 & $0.73^{* * *}$ & & & \\
\hline RE4 & $0.72^{* * *}$ & & & \\
\hline RE5 & $0.74^{* * *}$ & & & \\
\hline Self confidence & & 0.93 & 0.85 & 0.94 \\
\hline SC1 & $0.76^{* * *}$ & & & \\
\hline SC2 & $0.73^{* * *}$ & & & \\
\hline SC3 & $0.78^{* * *}$ & & & \\
\hline Contacts & & 0.90 & 0.87 & 0.95 \\
\hline $\mathrm{CO} 1$ & $0.72^{* * *}$ & & & \\
\hline $\mathrm{CO} 2$ & $0.68^{* * *}$ & & & \\
\hline $\mathrm{CO} 3$ & $0.68^{* * *}$ & & & \\
\hline Perceived Employability & & 0.92 & 0.75 & 0.93 \\
\hline PE1 & $0.68^{* * *}$ & & & \\
\hline PE2 & $0.84^{* * *}$ & & & \\
\hline PE3 & $0.83^{* * *}$ & & & \\
\hline PE4 & $0.84^{* * *}$ & & & \\
\hline PE5 & $0.77^{* * *}$ & & & \\
\hline
\end{tabular}

Note: ${ }^{* * *} \mathrm{p}<.001 ; \mathrm{AVE}$, average variance explained; CR, composite reliability

Source: Author's Calculation

Table 3 indicates discriminant validity of the scales. Discriminant validity was assessed using two tests: firstly correlations among all the constructs were investigated to be below the maximum limit of 0.8 (Hair et al., 1998), secondly square of correlation between each pair of variable was checked not to exceed AVE for each variable (Fornell and Larcker, 1981).
Model test

Table 4 shows the model fit results, which was tested using adjustment fit measures such as CFI, TLI, SRMR and RMSEA, following recommendations from literature. For $\mathrm{CFI}$ and TLI values were denoted above the recommended value of 0.9 (Bentler and Bonett, 1980; Bollen and Long, 1993). RMSEA indices were found to be under acceptable range of 
0.05 to 0.08 (Levy and Varela, 2003). SRMR was found to be less than 0.08 , which is considered a good fit (Hu and Bentler, 1999). in different academic disciplines such as human resource management, education and sociology.

Table 3: Discriminant validity of the scales

\begin{tabular}{|l|c|c|c|c|c|c|c|c|}
\hline Variable & 1 & 2 & 3 & 4 & 5 & 6 & 7 & 8 \\
\hline Generic Skills & 0.71 & 0.679 & 0.386 & 0.319 & 0.542 & 0.489 & 0.287 & 0.287 \\
\hline University Role & $0.824^{* * *}$ & 0.788 & 0.356 & 0.293 & 0.413 & 0.444 & 0.327 & 0.268 \\
\hline $\begin{array}{l}\text { Academic } \\
\text { Performance }\end{array}$ & $0.621^{* * *}$ & $0.597^{* * *}$ & 0.814 & 0.167 & 0.145 & 0.246 & 0.067 & 0.188 \\
\hline Contacts & $0.565^{* * *}$ & $0.541^{* * *}$ & $0.409^{* * *}$ & 0.874 & 0.138 & 0.141 & 0.047 & 0.125 \\
\hline Labor Market & $0.736^{* * *}$ & $0.643^{* * *}$ & $0.381^{* * *}$ & $0.371^{* * *}$ & 0.824 & 0.321 & 0.243 & 0.133 \\
\hline Reflection & $0.699^{* * *}$ & $0.666^{* * *}$ & $0.496^{* * *}$ & $0.376^{* * *}$ & $0.567^{* * *}$ & 0.809 & 0.219 & 0.212 \\
\hline Self confidence & $0.536^{* * *}$ & $0.572^{* * *}$ & $0.258^{* * *}$ & $0.217^{* * *}$ & $0.493^{* * *}$ & $0.468^{* * *}$ & 0.854 & 0.116 \\
\hline $\begin{array}{l}\text { Perceived } \\
\text { employability }\end{array}$ & $0.536^{* * *}$ & $0.518^{* * *}$ & $0.434^{* * *}$ & $0.354^{* * *}$ & $0.365^{* * *}$ & $0.46^{* * *}$ & $0.341^{* * *}$ & 0.754 \\
\hline
\end{tabular}

Note ${ }^{* * *} \mathrm{p}<.001$, Correlation square values: above the diagonal, Correlation values: below the diagonal, AVE values: along the diagonal

Source: Author's Calculation

Table 4: Model fit indices

\begin{tabular}{|c|c|c|c|c|c|c|}
\hline \multicolumn{9}{|c|}{} & \multicolumn{2}{c|}{ RMSEA 90\% CI } \\
\hline$\chi^{\mathbf{2}}$ & CFI & TLI & SRMR & RMSEA & Lower & Upper \\
\hline 7020 & 0.916 & 0.91 & 0.0559 & 0.0734 & 0.0713 & 0.0756 \\
\hline
\end{tabular}

Source: Author's Calculation

\section{Theoretical implications:}

This study substantiates the importance of identified key determinants for perceived employability in Indian context. It will add value to the current area of research and literature in media studies. This study supports human capital theory, by confirming the importance of education with reference to academic performance of students in enhancing employability. Assisting social capital theory, this study highlights the significance of social capital with reference to contacts and networking to enhance employability.

\section{Managerial implications:}

This study will aid recruiters to base and streamline their recruitment and selection plans. Moreover, this study will help in providing employable students by making them aware of corporate expectation and requirement. Additionally, policy makers can use the proposed model to draft their educational policies to increase the employment rate in India. Finally, researchers can use this validated model for future studies

\section{Practical implications}

University student, faculty, policy makers and researchers will be interested to know the results of this study. For students, this study provides a self-assessment tool which can be used to identify and develop factors leading to enhanced employability. This study is important for universities and its faculty as it provides information related to the importance of various university practices in enhancement of student employability so that they can cater employable student to labor market.

Limitations of the study and recommendation for future research

Validation of scale in Indian context specifically focusing on Delhi/NCR location only is the first limitation as it may not be applicable to different labor market situation. Secondly this study substantiate the proposed model at exploratory and confirmatory level but do not describe the structural relationship among different variables, which act as a line for future research based on the present study. Some relevant variables might have been 
excluded in this study due to practical limitations, which tends to be another limitation. Finally, the present study uses cross-sectional research design and future studies could be based on longitudinal research design.

\section{DISCUSSION \& CONCLUSION}

The objective was to find out how perceived employability is build and enhanced in university students. Theoretical model composed of key determinants was intended in this study. The suggested model is more holistic and comprehensive in nature with comparison to preceding models. This study aims to confirm and validate the scale in reference to Indian context. We have classified the factors into internal and external factors. Further, internal factors comprised of person specific factors (generic skills-basic literacy, critical thinking, interpersonal, leadership, problem solving; reflection and evaluation; academic performance) and environment specific factors (contacts). External factors comprised of university specific factors (career education, employment assistance, exposure to real world activities, exposure to work experience and teacher assistance) and social factor (labor market). Another determining variable of the study was self-confidence. For all the variables, scales were drawn from literature and were validated at exploratory and confirmatory level to broaden the existing conceptualization and for the purpose of scale validation at confirmatory level. All the variables were reflective and their psychometric properties were assessed such as content validity, convergent validity, discriminant validity, reliability and unidimensionality. The results showed that generic skills and university role are multidimensional while other variables are unidimensional.

\section{REFERENCES}

Andrews, J. and Higson, H. (2008), "Graduate employability, 'soft skills' versus 'hard' business knowledge: a European study", Higher Education in Europe, Vol. 33 No. 4, pp. 411-422.

Bandura, A. (1986), Social Foundations of Thought and Action: A Cognitive Theory, Prentice Hall, Englewood Cliffs, NJ.

Becker, G. (1975), Human Capital: A Theoretical and Empirical Analysis, with
Special Reference to Education. Cambridge, MA: NBER.

Bentler, P.M. (1990), “Comparative fit indexes in structural models", Psychological Bulletin, Vol. 107 No. 2, pp. 238-246.

Bentler, P.M. and Bonett, D.G. (1980), "Significance tests and goodness of fit in the analysis of covariance structures", Psychological Bulletin, Vol. 88 No. 3, pp. 588-606.

Berntson, E., Sverke, M. and Marklund, M. (2006), "Predicting perceived employability: human capital or labour market opportunities?", Economic and Industrial Democracy, Vol. 27 No. 2, pp. 223-244.

Caballero, G., López-Miguens, M.J. and Lampón, J. (2014), “La universidad y su implicación con la empleabilidad de sus graduados", Revista Española de Investigaciones Sociológicas (REIS), Vol. 148 No. 1, pp. 23-45.

Chou, C.M. and Shen, C.H. (2012), "Factors influencing employability self-efficacy of engineering students in Taiwan", International Journal of Engineering Practical Research, Vol. 1 No. 1, pp. 10-14.

Dacre, P.L. and Sewell, P.J. (2007), “The key to employability: developing a practical model of graduate employability", Education+Training, Vol. 49 No. 4, pp. 277-289.

De Vos, A., De Hauw, S. and Van der Heijden, B.I. (2011), “Competency development and career success: the mediating role of employability", Journal of Vocational Behavior, Vol. 79 No. 2, pp. 438-447.

Finch, D.J., Hamilton, L.K., Baldwin, R. and Zehner, M. (2013), “An exploratory study of factors affecting undergraduate employability", Education+Training, Vol. 55 No. 7, pp. 681-704.

Finch, D.J., Peacock, M., Levallet, N. and Foster, W. (2016), “A dynamic capabilities view of employability: exploring the drivers of competitive advantage for university graduates", Education+ Training, Vol. 58 No. 1, pp. 61-81.

Fornell, C. and Larcker, D.F. (1981), "Evaluating structural equation models with unobservable variables and 
measurement error", Journal of Marketing Research, Vol. 18 No. 1, pp. 39-50.

Fugate, M., Kinicki, A.J. and Ashforth, B.E. (2004), “Employability: a psycho-social construct, its dimensions, and applications", Journal of Vocational Behavior, Vol. 65 No. 1, pp. 14-38.

Gamboa, J.P., Lerin, F.J.G., Botella, P.R. and Silla, J.M.P. (2007), “La empleabilidad y la iniciativa personal como antecedentes de la satisfacción laboral", working papers: Serie EC Instituto Valenciano de Investigaciones Económicas, Vol. 1, No. 1, Valencia.

Hair, J.F., Anderson, R.E., Tatham, R.L. and Black, W.C. (1999), Análisis Multivariante, $5^{a}$ edición, Prentice Hall, Madrid.

Hernández-Fernaud, E., Ramos-Sapena, Y., Negrín, F., Ruiz-de la Rosa, C. and Hernández, B. (2011), “Empleabilidad percibida y autoeficacia para la búsqueda de empleo en universitarios", Revista de Psicología del Trabajo y de las Organizaciones, Vol. 27 No. 2, pp. 131-142.

Hildebrandt, L. (1987), “Consumer retail satisfaction in rural areas: a reanalysis of survey data", Journal of Economic Psychology, Vol. 8 No. 1, pp. 19-42.

Hillage, J. and Pollard, E. (1998), Employability: Developing a Framework for Policy Analysis, Department for Education and Employment, London.

Jackson, D. (2015), “Employability skill development in work-integrated learning: barriers and best practice", Studies in Higher Education, Vol. 40 No. 2, pp. 350367.

Kim, S., Kim, H. and Lee, J. (2015), “Employee self-concepts, voluntary learning behavior, and perceived employability", Journal of Managerial Psychology, Vol. 30 No. 3, pp. 264-279.

Lévy, J.P. and Varela, J. (2003), Análisis multivariable para las ciencias sociales, Pearson Educación, S.A., Madrid.

Luque, T. (2000), Técnicas de análisis de datos en investigación de mercados, Pirámide, Madrid.

Mason, G., Williams, G. and Cranmer, S. (2009), "Employability skills initiatives in higher education: what effects do they have on graduate labour outcomes?", Education Economics, Vol. 17 No. 1, pp. 130.

McQuaid, R.W. and Lindsay, C. (2005), "The concept of employability", Urban Studies, Vol. 42 No. 2, pp. 197-219.

Nunnally, J.C. (1978), Psychometric Theory, 2nd ed., McGraw Hill, New York, NY.

Oluyomi, S.P and Colette, M. (2019), "University reputation and undergraduates' self-perceived employability: mediating influence of experiential learning activities", Higher Education Research \& Development, DOI: 10.1080/07294360.2019.1634678.

Oluyomi, S.P and Colette, M. (2019), 'Students' self-perceived employability (SPE) Main effects and interaction of gender and field of study", Higher Education Skills and Work-based Learning, Vol. 10 No2. pp 355-368.

Peeters, E. R., Akkermans, J., \& De Cuyper, N. (2020). "The Only Constant Is Change? Movement Capital and Perceived Employability". Journal of Career Assessment, Vol. 20 No. 1, pp 1-19.

Qenani, E., MacDougall, N. and Sexton, C. (2014), "An empirical study of selfperceived employability: improving the prospects for student employment success in an uncertain environment", Active Learning in Higher Education, Vol. 15 No. 3, pp. 199-213.

Nagoma, M. and Ntale D.P. (2016), "Psychological capital, career identity and graduate employability in Uganda: the mediating role of social capital", International Journal of Training and Development, Vol. 20 No. 2

Rothwell, A. and Arnold, J. (2007), "Selfperceived employability: development and validation of a scale", Personnel Review, Vol. 36 No. 1, pp. 23-41.

Rothwell, A., Herbert, I. and Rothwell, F. (2008), "Self-perceived employability: construction and initial validation of a scale for university students", Journal of Vocational Behavior, Vol. 73 No. 1, pp. 1

Sabatini, F. (2009), "Social capital as social networks: a new framework for 
measurement and an empirical analysis of its determinants and consequences", The Journal of Socio-Economics, Vol. 38 No. 3, pp. 429-442.

Shiva, A., Narual, S., Shahi, K.S, (2020), “What drives retail investors' investment decision? Evidence from no mobile phobia (Nomophobia) and investor fear of missing out (I-FOMO)", Journal of content, community \& communication, Vol. 11 No.1, pp.8.

Srivastava, K., Prabhakar, A, (2020), “A predictive model of expressiveness based on demographic and socio-economic factors of the Indian youth: A selfperception", Journal of content, community \& communication, Vol. 11 No.1, pp.2-3.

Stuart Rosenberg, Ronald Heimler, Elsa-Sofia Morote, (2012) "Basic employability skills: a triangular design approach", Education
+ Training, Vol. 54 No. 1, pp.7-20, https://doi.org/10.1108/004009112111988 69

Tsui, A.S., Pearce, J.L., Porter, L.W. and Tripoli, A.M. (1997), "Alternative approaches to the employee organization relationship: does investment in employees pay off?", Academy of Management Journal, Vol. 40 No. 5, pp. 1089-1121.

Van der Heijde, C. and Van der Heijden, B. (2006), "A competence-based and multidimensional operationalization and measurement of employability", Human Resource Management, Vol. 45 No. 3, pp. 449-476.

Wittekind, A., Raeder, S. and Grote, G. (2010), "A longitudinal study of determinants of perceived employability", Journal of Organizational Behavior, Vol. 31 No. 4, pp. 566-586. 